\title{
Extent of Implementing Target Costing and Value Engineering Approach to Reducing Costs: A Survey in Jordanian Shareholding Companies for Food Industries
}

\author{
Prof Suleiman Mustafa El- Dalahmeh \\ Faculty of Economic and Administrative Science \\ Accounting Department -Jerash University \\ E-mail: Dr.el-dalahmeh97@live.com
}

Received: Jan. 3, $2018 \quad$ Accepted: Feb. 22, $2018 \quad$ Published: June 1, 2018

doi:10.5296/ajfa.v10i1.12606 URL: https://doi.org/10.5296/ajfa.v10i1.12606

\begin{abstract}
This Study aims at identifying the extent of implementing Target Costing and Value Engineering approach to reducing costs of Jordanian public shareholding companies for food industries. To achieve the study objectives, the researcher distributed personally a questionnaire to a random sample of (145) accountants in the Hashemite kingdom of Jordan. (100) questionnaires were returned. The response rate was $69 \%$. In addition, the survey sought to verify the five basic hypothesis of the study. In order to analysis the data, the researcher used means, standard deviations and T-test. The results of the survey revealed that availability of the components of application of target cost, as well as companies have awareness, concepts, principles and the importance of applying target costs to managing costs so as to improve profitability, and the companies are using value engineering to achieve a cost to reach the target costs. The results also showed that there were some difficulties to hinder the application of target costs and value engineering in Jordanian shareholding companies for food industries. The most important difficulties were: The lack of sufficient knowledge to manage the company on how to implement the target cost and value engineering. The lack of research and publication related to the benefits target cost and value engineering. Application costs greater than the expected benefits.
\end{abstract}

Keywords: Target costs, value engineering, management accounting, the Jordanian shareholding companies for food industries. 


\section{Introduction}

The world is witnessing huge technological developments in the production on and management systems from Japanese companies and most of the major industrial companies in most of the developed countries, also, these have achieved remarkable successes for Japanese companies, making them the world's leading companies interims of cost control and high level of quality. There is no doubt that theses development in administrative thought and production technology have been accounting thought, especially in the field of managerial accounting and information systems supporting administrative decisions.

The introduction of Target Costing and Value Engineering has emerged as one of the important approaches in marrying costs through reducing them, while maintaining quality. Due to the important of target costs and value engineering in reducing costs, whether the Shareholding companies for food industries in Jordan have begun to manage their costs through their use of the target cost approach and value engineering as an entrance to reducing costs.

\section{The Problem of Study}

The problem of study is to identify the extent of the implementation of the target costs of the Jordanian as entrance to reducing costs of the Jordanian shareholding industrial companies.

\section{The Importance of the Study}

The importance of this study comes from the importance of implementing the target costs and value engineering as entrance to reducing costs of the shareholding companies for food industries in Jordan.

\section{Purposes of the Study}

This study seeks to achieve the following objective:

1- Identify the availability of the components of implementing target costing entrance in shareholding companies for food industries in Jordan.

2- Identify the extent to which Jordanian shareholding companies for food industries are aware of concepts, principles and importance of using the target cost approach.

3- The extent to which Jordanian shareholding for food industries companies use the cost target to manage their costs to improve profitability.

4- The extent to which Jordanian shareholding companies for food industries use the value engineering to reduce the cost of its products to reach the target cost.

5- To identify the difficulties that hinder the adoption of the Target Costing and Value Engineering in Jordanian shareholding companies for food industries in Jordan. 


\section{Terminology of Study}

- Target costs: one of methods of management accounting for cost management, which aims to reduce the cost of product during the stages of planning design and product development with high quality to satisfy the desires and needs of customers and reach a predefined value of cost under the market prices of the product produced. (Horngran. etal,2011,p218).

- Value engineering is searches to potential areas of cost reduction during the product planning design of the product, while maintaining the functional status and quality of product (Hilton, 2005, p233).

\section{Literature Review}

In the accounting literature much has been written about the implementing target costing and value engineering entrance to reducing cost, the concept of target cost was introduced in 1973 in Japan. The association of Japanese accountants has been defined target cost as a profit management process by determining the product quality, price, distribution and other product -related objective that enable the company to achieve its profit strategy, this is achieved during the planning design and developing the product to the level that meets the needs of customers (http://www.JPS-dir.com /forum /uploads/13379/what target cost. PDF). since 1995, there has been increased interest in studying the implementing of the target cost after the application showed positive results in Japan.

Researcher's opinions in the Target Cost field are divided into two groups:

First groups see the target cost as a cost -cutting tool without being exposed to its impact in profitability planning (Monden \& Hamad,1991,p16) defined target cost as a system that helps reduce costs in the design of the new product or when the design model of the current product is completely changed or the model is partially modified. (Lgangne \& Discenza, 1993, p34) explained the concept of target cost as a method of accounting management aimed at cost management during the stage of planning and design of product in order to save the ongoing costs using various optimization tools such as value engineering.

(Kaplan, 1998, p61) believes that the target cost is the most effective way to support competitive advantages in order to reduce cost and achieve customer satisfaction. (cooper \& Salgmulder, 2003, p60) said that the target cost is the most effective way to maintain low-cost as well as the manufacturing phase of the product life cycle. In the same vine, Kazizen sees it is a cost - planning and design to reduce cost in the manufacturing phase to the required levels (Davies \& Boczko, 2005, p437). Moreover, (Kee.R \& Matherly 2006, p268) introduced a definition of target cost as a cost control tool to help control the costs that occur during the product life cycle from the design stage. Furthermore, (Garrison, etal 2011, p723) pointed out that the target cost process of determining the maximum permitted costs for a new product and through the development of an initial model can provide the maximum target cost. 


\section{MlMacrothink}

Asian Journal of Finance \& Accounting

ISSN 1946-052X

2018, Vol. 10, No. 1

From the point of view of the second group, the target cost approach is a method aimed at improving the profitability of the enterprise and reducing costs. In other words, the target cost is a process aimed at reaching the desired financial results of the product at a given time by reducing the cost and improving profitability (The difference between the expected selling price and profit ability planned establishment). (Castellano \& Young,2003,p144) explained the target cost as a profit planning and cost management system based on sales price, costumer focus, product design and an integrated team that is committed to implementing the system. In this regards, (Hematfaret al, 2011, p3) concluded that target cost is a process to determine the target cost of new products before they are produced by providing the cost information intended for design engineers to achieve the application of new cost management in order to ensure the profitability of the new product when it is put on the market.

\subsection{Advantages of Target Cost}

Nowadays, companies face severs pressures from different stakeholders to keep prices low and to increase their profit at the same time. Thus, they use different strategies to increase profits without affecting price. One of these strategies is Target Costing. (Hilton, 2005, p650) (Ellarm, 2001, p11)(Garrison \& etal, 2001, p720) (Okana \& Suzk, 2007, p176) (Collier \& knight, 2008,p p 7-8) (Bahar, M.2012,p p 21-33) pointed out many advantages to the target cost, include; Contributes to the strategic management of future profit; It is a tool for managing cost and profitability simultaneously; Reduce costs from product planning and design to after sales; Important tool to control the promotion of management awareness of costs; Cost control by comparing actual costs with target costs; Target costs approach works; Target cost encourages team work; Achieves continuous cost reduction for its reliance on continuous improvement as a value engineering entry; and Achieves positive interaction between the internal environment of establishment and the extranet environment (customers and suppliers).

\subsection{Components Application of Target Cost Approach}

(Hilton, 2005, p649) (Yazdifar \& Askarony 2011, p p2-6) (Evera, et al. 2006) (CIMA, 2005, p4) noted that the implementation of target cost approach is based on the following basic components:

1- Price - led costing: Target cost $=$ Target profit - Target price.

2- Focus on the costumer: management needs to know consumers preferences about the product and the price that suits them.

3- Focus on product design: this means designing the product in a way that can be produced without exceeding the target cost.

4- Focus on process design: this requires examining the aspects of the production process to ensure that the product is manufactured at the highest possible cost.

5- Cross - Functional Teams: this requires the cooperation of all the different task forces in the establishment. 
6- Life cycle costs: taking all costs related to the life cycle of the product in to account.

7- Value chain orientation: Cancel all costs that don't add value in order to reduce the planned cost.

The researcher believes that the goal of the target cost is to reduce costs without prejudice to specifications of the product and maintain the level of feasibility required by the client. The cost of the product is reduced and reached to the target cost through the following stages: (Hematfar, et al. p p3-7) (Ansari, 1997 p10) (Williams\& et al, 2005, p811) (Hilton 2005 p 651) (Ibuski \& Kaminski, 2007, p459)

1- Planning and product design.

2- Cost analysis phase.

3- Value engineering phase (value analysis).

4- Production phase (final decision).

\subsection{Use The Value Engineering in Achieving the Target Cost:}

The entrance of value engineering is one of the main tools that production designers use to achieve their target cost. The value engineering seeks to find potential areas for cost reduction during the product design and planning phase as an integral to the target cost approach. The important aspect of value engineering is to achieve a certain level of cost reduction. In other words, value engineering aims at reducing the gap between the estimated cost of the product and the allowable cost (Blocher. et al, 2008, p p362-365).

\subsection{The Difficulties That Facing the Adoption of the Target Cost Approach}

The difficulties that facing the adoption of the target cost approach:(Yoshikawa etal, 1993 pp.211-214) pointed out that there are a number of difficulties that impede the adoption of the target cost approach.

1- The concept of the Target Costing and Value Engineering is not clear in practice in many economic units.

2- Rapid technological development.

3- The difficulty of predicting in new competitors.

4- The difficulty of managing the target cost to achieve the target cost.

5- The continuous rise in prices of raw materials.

6- Great pressure on employees to reach the target cost within a specified time frame.

7- Lack of full product cost information.

8- The unpredictability of future customer desires. 


\subsection{Previous Studies}

a number of studies have been undertaken about the topic of the study; particularly the application of the target cost entrance to reducing costs of production.

(Ratlray, et al (2007)) examined the extent of implementing target costing in New Zealand manufacturing firms. The study was conducted on (80) industrial companies in New Zealand. The study revealed that the production department contributes effectively to achieving the target cost through the addition of improvements to the product design and modifications to the manufacturing methods, which led to the reduction of costs to be equal to the target cost.

(Kocsoy,et al, (2008)) the study aimed to how the Turkish industrial projects benefit from modern techniques in administrative accounting and the most important of these methods is the target cost the study showed that companies must follow a parallel competitive strategy especially that majority of companies operate under competitive market conditions and in order for companies to achieve the expected benefits of the target costs, they must pay great attention to customer expectation before designing the product.

(Filomena \& et. al (2009)). This study was conducted in Brazil and aimed to activate the target cost through product development as a model for implementing by recognizing the experience of the cost of product development at any stage in medium sized Brazilian enterprises by applying the cost target model. The study concluded that the participants in the procurement of special engineers and designers are more the precisely controlling the cost, as the study showed that there were limitations in the lack of discussion of the specific cost estimate and cost reduction techniques.

(Yazdifor \& Ashkarany (2011)) The study aimed at comparing the adoption and application of the target cost in the United Kingdom, Australia and New Zealand by applying them to qualified administrative accountants with a legal administrative accounting certificate who work in the (2041) industrial and service companies. The researchers used the survey method in their study the distribution of (584) questionnaires. The results of the study showed that the prevalence of the use of the target cost approach between the industrial and service companies in the countries in which the study was conducted and there is an increasing interest of companies in testing all the cost reduction strategies at the stage of plan and adopt value engineering to integrate customer requirements rather than to adopt a cost cutting strategy.

(Alkababji (2014)) this study was conducted in Palestine and aimed at the availability of components of the application of the target cost entrance in the industrial companies of the Palestinian. (11) Companies have represented the study sample, (9) industrial public shareholding companies responded to the researcher. The study revealed that ingredients of implementing target costing entrance in industrial companies, which means that the Palestinian industrial companies have appropriate environment for using the target costing, also the results showed that were some difficulties which could hinder the application.

(Norhafiza Bashrudin \& RuzitaJuson, 2015) This study was conducted in Malaysia. The purpose of the study is to explore how the target cost method is being practiced and what the 
major factors are that influence target cost method in non-Japanese environment.according to the researchers the results of the study showed that the fundamental concept of target cost practices at the case company was similar to the Japanese companies practices in spite of the were some difference in details. The differences were due to the case company coordinated and reconfigured its resources to adopt with the contextual constraints as highlighted in four propositions developed this study focused on a single case study in a single industry.

(Talebnia, G. et al, 2017) studied the linkages between Target costing and Value Engineering and Expected profit and Kaizen. The results of study showed that there is a relation between customer orientations, the product has a direct effect on target costing and Product Lifecycle costs are directly related to the objectives.

(Bock, S \& Pütz, M, 2017) proposed new quality-oriented control approach for Value Engineering based on a discrete quality measure that allows for the mapping of multidimensional dependencies. They found that understanding the decision-making process in sales and production departments, and their frequent application provides systematic access to controlled operations and, in doing so, supports management-oriented decision-making.

\section{Hypotheses of the Study}

H01: The Jordanian shareholding companies for food industries don't have the ingredients to implement the target cost approach.

H02: The Jordanian shareholding companies for food industries do not awareness the concept, principles and importance of applying the target cost approach.

H03: The Jordanian shareholding companies for food industries do not use the target cost management to improve their profitability.

H04: The use of value engineering does not reduce costs to reach the target cost in the Jordanian shareholding companies for food industries.

H05: There are no difficulties in adopting the cost target and value engineering in Jordanian shareholding companies for food industries.

\section{Methodology and Discussion of Results}

\subsection{Methodology}

The study reveals the results of a survey of accountants in shareholding companies for food industries in Jordan regarding the extent of implementing Target Costing and Value Engineering entrance to reducing costs in Jordanian shareholding companies for food industries. The questionnaire was distributes personally to a random sample of 145 accountants. (100) questionnaires were returned, and the response rate of which was $69 \%$. It is to be noted that a majority of the respondent, have a Bachelor's degree in accounting, as well as professional qualification such as CPA, JCPA. Average experiences of respondent were about (10) years with a maximum more than (15) years and a minimum of (5) years at 


\section{Macrothink}

Asian Journal of Finance \& Accounting

ISSN 1946-052X 2018, Vol. 10, No. 1

the time of conducted this survey. The purpose of the above analysis was to ensure that accounting professional who have experience who completed the survey.

\subsection{Study Tools}

After reviewing the literature of accounting and previous studies that relating to Target Costing and Value Engineering entrance to reducing costs. The researcher developed a questionnaire which consisted of (34) items regarding the adoption and implementation of target costing and value engineering entrance to reducing costs in the Jordanian shareholding companies for food industries.

\subsection{Statistical Tests}

Statistical methods Applied to analyze data are means, standard deviations and percentages and $\mathrm{T}$ - test.

\section{Scale}

Likert scale was adopted, which consists of five degrees to determine how much the responders agree or disagree with each item in the questionnaire as how in table (1).

Table 1. Likert scale

\begin{tabular}{llllll}
\hline Scale & $\begin{array}{l}\text { Strongly } \\
\text { Disagree }\end{array}$ & Disagree & Neutral & Agree & $\begin{array}{l}\text { Strongly } \\
\text { Agree }\end{array}$ \\
Degree & 1 & 2 & 3 & 4 & 5 \\
$\begin{array}{l}\text { Relative } \\
\text { weight }\end{array}$ & $20 \%$ & $40 \%$ & $60 \%$ & $80 \%$ & $100 \%$ \\
\hline
\end{tabular}

8.4 Results Analysis and Discussion 
Table 2. Trends of the sample of the study on the availability of components of the application of the target cost in Jordanian share holding companies for food industries.

\section{No Items}

1

The company uses a cost accounting system that is commensurate with its activity

2

The management of the company is interested in managing its costs

The company determines the price at which the

3 product can be sold by subtracting the price from the target cost

The company determines the cost of its product as

4 following (expected selling price - profit required $=$ target cost)

5 The company is interested in the customers desires related to the product and price

The company designs it's product according to

6 planned allowable and eliminate costs that do not add value

7 The company manufactures its products efficiently without exceeding the permitted cots

8

The company is composed of teams from various departments to achieve the planned cost
Mean

4.84

4.76

0.47

$95.20 \%$

$\begin{array}{ll}4.50 & 0.58\end{array}$

$90 \%$

$\begin{array}{ll}4.42 & 0.56\end{array}$

$88.40 \%$

$\begin{array}{ll}4.31 & 0.78\end{array}$

$86.20 \%$

$4.21 \quad 0.81$

$84.20 \%$

$4.11 \quad 0.70 \quad 82.20 \%$

$4.04 \quad 0.63 \quad 81.10 \%$

General Average

$\begin{array}{ll}4.405 & 0.61\end{array}$

$\mathbf{8 8 . 1 0} \%$

Table 2 shows that the trends of the sample of the study are positive in all items about the availability of the ingredients of the implementation of the target cost in the Jordanian shareholding companies for food industries, where the general average (4.405) is greater than the mean of the study tool (3),the standard deviation ( 0.61$)$ and the percentage $(88.10 \%)$,also, the standard deviation (0.61) indicates to the agreement of the sample of the study on the availability of the target cost in Jordanian shareholding companies for food industries and the percentage $(88.10 \%)$ reinforce this. 
in order to test the hypotheses of the study the T-test was performed at a level of (0.05) according to the rule of decision: the null hypothesis accepted if the calculated (T) is less than (T) value and $\mathrm{SiG}$ value is greater than (0.05). The null hypothesis is rejected if the calculated $(\mathrm{T})$ value is greater than the $(\mathrm{T})$ value and the significant value equal or less than $(0.05)$.

HO1: The Jordanian shareholding companies for food industries do not have the ingredients to implementing the target cost approach.

Table 3. Results of T. test (first hypothesis)

\begin{tabular}{llllll}
\hline Sig & $\begin{array}{l}\text { Calculated(T) } \\
\text { Value }\end{array}$ & $\begin{array}{l}\text { Tabulated } \\
\mathbf{( T ) V a l u e}\end{array}$ & Mean & $\begin{array}{l}\text { Standard } \\
\text { Deviation }\end{array}$ & Results \\
0.00 & 14.680 & 1.9842 & 4.405 & 0.61 & Reject \\
\hline
\end{tabular}


Table 4. Trends of the sample study on the awareness of Jordanian shareholding for food industries for the el concepts a principles and importance of applying the target cost approach in managing their costs

N Items

The management of the company is concerned with

1 adopting the target cost approach to reduce their cost with preservatives required quality

Management company strives to know the competitive

2 price of the product for its impact in calculating the maximum allowable cost

The management of the company recognizes the importance of desires needs of consumers and their

3 tastes in terms of price and quality when reducing the costs to reach the target cost according to adopting the cost target approach

The company urges all department towards reducing

4 costs to reach the target cost which does not affect the quality of product

5

The company is aware that the cost reducing of the product is during the planning and design stages

\section{Mean \\ Standard Percent \\ Deviation age}

$4.34 \quad 0.934 \quad 86.80 \%$

$4.31 \quad 0.775 \quad 86.20 \%$

$4.30 \quad 0.69 \quad 86 \%$

$4.10 \quad 0.70 \quad 82 \%$

$4.24 \quad 0.71 \quad 84.80 \%$

$4.26 \quad 0.439 \quad 85.20 \%$

General average

Table 4 shows the results of the analysis show that Jordanian shareholding companies for food industries realize the concepts, principles, and importance of applying the target cost to manage their costs. This is evidenced by the general average of (4.26) as it is larger than the mean of the study tool (3) as the standard deviation of (0.439) indicates the absence of a large dispersion between the study sample opinions and enhances the approved level is $(85.20 \%)$.

HO2: The Jordanian shareholding companies for food industries do not awareness the concepts, principles and importance of using the target cost approach. 
Table 5. Results of T test (second hypothesis)

\begin{tabular}{llllll}
\hline Sig & $\begin{array}{l}\text { Calculated } \\
(\mathbf{T}) \text { Value }\end{array}$ & $\begin{array}{l}\text { Tabulated(T) } \\
\text { Value }\end{array}$ & $\begin{array}{l}\text { Standard } \\
\text { Deviation }\end{array}$ & Mean & Results \\
0.000 & 12.170 & 1.9842 & 0.439 & 4.26 & Rejects \\
\hline
\end{tabular}

Table 5 showed that the mean of the Jordanian shareholding companies for food industries awareness of the target cost in managing their costs is greater than the mean of the study tool (3) and the difference of (0.26) is considered significant based on the value of sig $=6.000$ which is less than 0.05 . There for the researcher rejects the null hypothesis and accepts the alternative hypothesis which stipulates that Jordanian shareholding companies for principles and importance of using the target cost in managing their cost.

Table 6. Trends of the sample study on the use of the target cost in management of their cost to improve profitability.

\section{No Items}

1

The target cost approach contributes in the strategic management to the future profits of the company

The target cost approach contributes to giving incentives to

2 the employees which leads to increased productivity and thus improved the level of profits

3

Using the target cost approach helps in minimize waste in cost elements to the maximum extent possible

The company is concerned with the results of analyzing the desires and needs of the target consumers when planning and designing the product that achieves the target cost and profit target

5

The company studies the market to identify new competitive products and competitors

The company determines the competitive price of the

6 product through the study of competitive prices in the market

The company is interested in applying total quality

7 management on productivity stages with the aim of improving profitability
Mean

4.32

4.24

0.75

4.21

0.64

$84 \%$

4.20

0.65

$82.40 \%$

$4.12 \quad 0.74$

$79.88 \%$

3.99

0.97

$79.80 \%$

3.95

0.99

$79 \%$

General average 


\section{Macrothink Institute ${ }^{\mathrm{TM}}$}

Table 6shows that the trends of the study sample on all the items were positive and ranged between (4.32-3.95) the general average (4.147) is greater than the mean of study tool (3) in addition to the standard deviation which indicates the absence of a large dispersion between the sample study. This result confirms that the Jordanian shareholding companies for food industries are using the cost target in managing their costs to improve profitability with a degree of approved $82.90 \%$.

H03: The Jordanian shareholding companies for food industries do not use the target cost management to improve their profitability.

Table 7. Results of T. test (third hypothesis)

$\begin{array}{lllllll}\text { SiG } & \text { Calculated (T) value } & \begin{array}{l}\text { Tabulated } \\ \text { value }\end{array} & \text { (T) } \begin{array}{l}\text { Standard } \\ \text { deviation }\end{array} & \text { Mean } & \text { Results } \\ 0.00 & 14.321 & 1.9842 & 0.644 & 4.147 & \text { Reject }\end{array}$

Table 8. Trends of the sample of the study on the use of the Jordanian shareholding companies for food industries the value engineering to reach the target cost

\begin{tabular}{llll}
\hline No Items & Mean & $\begin{array}{l}\text { Standard } \\
\text { Deviation }\end{array}$ & Percentage \\
$\mathbf{1}$ & $\begin{array}{l}\text { The company determines the cost of its products } \\
\text { during the planning and design stages }\end{array}$ & 0.40 & $88.00 \%$ \\
$\begin{array}{l}\text { The company has a design team of different } \\
\text { departments to provide the best product design } \\
\text { and achieve the target cost }\end{array}$ & 0.31 & $86.20 \%$ \\
$\begin{array}{l}\text { The company cancels activities that do not add } \\
\text { value to the product and incorporate similar }\end{array}$ & 4.22 & 0.70 & $84.40 \%$ \\
$\begin{array}{l}\text { activities } \\
\text { The company uses cost tables that include cost } \\
\text { drives to help select materials the are involved in } \\
\text { product manufacturing within the target cost level } \\
\text { The company encourages teamwork to reduce } \\
\text { waste }\end{array}$ & 3.01 & 0.35 & $80.20 \%$ \\
$\begin{array}{l}\text { The company is interested in the quality of similar } \\
\text { parts used in two or more manufactures to reduce } \\
\text { costs }\end{array}$ & 3.84 & 0.67 & $78.00 \%$ \\
General average & $\mathbf{4 . 1 0}$ & $\mathbf{0 . 3 8 8}$ & $\mathbf{8 2 . 0 0 \%}$ \\
\hline
\end{tabular}

Table 8 shows that the overall mean level of all the paragraphs was (4.10) with the standard deviation of (0.388) the mean for all the items ranged between (4.40-3.84).

The relative importance of all items was $82 \%$. 
H04: The use of value engineering does not reduce costs to reach the target cost in the Jordanian share holding companies for food industries.

Table 9. Results of T test (forth hypothesis)

\begin{tabular}{|c|c|c|c|c|c|c|}
\hline Sig & $\begin{array}{l}\text { Calculated } \\
\text { Value }\end{array}$ & (T) & Tabulated (T) Value & Standard Deviation & Mean & Result \\
\hline 0.00 & 17.051 & & 1.9842 & 3.88 & 4.10 & Reject \\
\hline
\end{tabular}

Table 10. Trends of the study sample on the difficulties that facing the adoption of Target Costing and Value Engineering in Jordanian shareholding companies for food industries.

\section{No Items}

Lack of sufficient knowledge to manage the

1 company on how to implement the Target

Costing and Value Engineering approach.

Lack of research and publications related to

2 the introduction of the target cost and value engineering.

3 Application costs increased the expected benefit

4

Lack of clear and detailed information on product cost

Lack of training for the employees on the

5 implementation of the target cost and value engineering

6 The Difficulty of predicting new

General average

\section{Mean $\begin{array}{ll}\text { Standard } \\ \text { Deviation }\end{array}$}

Percentage

$3.07 \quad 0.76$

$81.40 \%$

$3.97 \quad 1.10$

$79.40 \%$

$3.85 \quad 0.96$

$77.80 \%$

$3.41 \quad 0.87$

$68.20 \%$

$3.75 \quad 0.48$

$75.00 \%$

$3.34 \quad 0.88$

$66.80 \%$

$3.75 \quad 0.319$

$75 \%$

Table 10 indicates that the general average (3.75) the standard deviation (0.931) and the degree of approval $(75 \%)$ this means that the average degree of difficulties hindering the adoption of the target cost and the value engineering in the shareholding companies for food industries is higher than the mean of the study tool (3) also the standard deviation of $(0.391)$ indicates a sample study agreement that there are difficulties impeding the adoption of Target 
Costing and Value Engineering approach in Jordanian shareholding companies for food industries.

H05: There are no difficulties in adopting the cost target and value engineering in Jordanian shareholding companies for food industries.

Table 11. Results of T. test (fifth hypothesis)

\begin{tabular}{lllllll}
\hline Sig & $\begin{array}{l}\text { Calculated } \\
\text { Value }\end{array}$ & $(\mathbf{T})$ & Tabulated (T) Value & $\begin{array}{l}\text { Standard } \\
\text { Deviation }\end{array}$ & Mean & Results \\
0.000 & $13.380^{\circ}$ & 1.9842 & 0.931 & 3.75 & Reject \\
\hline
\end{tabular}

\section{Conclusion}

The results of survey revealed that there is agreement in the opinion of the study sample on the availability of the components of the application of the target costs approach, as well as on the awareness of the Jordanian shareholding companies for food industries regarding their costs to improve profitability. In addition, the Jordanian shareholding companies for food industries are using the value engineering approach to achieve a cost reduction to reach the target cost. The results also indicated that there were some difficulties which hider the application of Target Costing and Value Engineering in the Jordanian shareholding companies for food industries. The most important difficulties were:

1- The lack of sufficient knowledge to manage the company on how to implement the target cost and value engineering.

2- The lack of research and publication related to the benefits target cost and value engineering.

3- Application costs greater than the expected benefits.

The results of the survey confirm the results of previous studies such as that conducted by Alkababji (2014). The researcher believes that Jordanian Shareholding Industrial Companies Which do not Apply Target Costing and Value Engineering will not be able to Fulfill the Desires and Expectations that are Placed upon them by Customers

\section{References}

Ansari, S. L., \& Bell., J. (1997). Target Costing: The Next Frontier In Strategic Cost Management. New York: Megraw-Hill.

Bahar, M. (2012). Conceptual Framework For Launching And Implementing Target Costing In Automotive Industry. International Journal of Research in IT \& Management, 2(6), 21-33.

Bhimani, A., Horngren, C. T., Sundem, G. L., Stratton, W. O., Schatzberg, J., \& Burgstahler, D. (2012). Introduction to Management Accounting. Pearson 
Blocher, E., Stout, D., Juras, P., \& Cokins, G. (2016). Cost Management-A Strategic Emphasis, Megraw-Hill Irwin

Bock, S. \& Pütz, M. (2017). Implementing Value Engineering Based on a Multidimensional Quality-Oriented Control Calculus within a Target Costing and Target Pricing Approach. International Journal of Production Economics, 183, 146-158. https://doi.org/10.1016/j.ijpe.2016.09.007

Castellano, F., \& Young, S. (2003). Speed Splashier: An Interactive, Team-Based Target Costing Exercise. Journal Of Accounting Education, 84(2), 293-305.

Cooper, R. \& Slagmulder, R. (1999). Develop Profitable New Products with Target Costing. MIT Sloan Management Review.

Davies, T., \& Boczko, T. (2005). Business Accounting and Finance, McGraw Hill Higher Education.

Ellram, L. M. (2001). The Role of Supply Management In Target Costing. Arizona State University, Arizona.

Evereat.P, Loosveld.S,.T, A., Schollier.M, \& Sarens.G. (2006). Characteristics Of Target Costing: Theoretical And Field Study Perspective. Qualitative Research In Accounting And Management, 3(3), 236-263. https://doi.org/10.1108/11766090610705425

Garrison, R., Noreen, E., \& Brewer, P. (2011). Managerial Accounting, Megraw-Hill Irwin.

Hematfar, M., Sanati-arasteh, A., \& Nooryan, S. (2009). The Steps of Implementing Target Costing, SSRN. Available: https://papers.ssrn.com/sol3/papers.cfm?abstract_id=1455184

Hilton, R. W. (2005). Managerial Accounting: Creating Value in a Dynamic Business Environment. New York: Megraw Hill.

Ibusuki, U., \& Kaminski, P. C. (2007). Product development process with focus on value engineering and target-costing: A case study in an automotive company. International $\begin{array}{llll}\text { Journal of Production } & \text { Economics, } & \text { 105(2), }\end{array}$ https://doi.org/10.1016/j.ijpe.2005.08.009

Knight, K., \& Collier, P. M. (2009). Target Costing in the Automotive Industry: A Case Study of Dynamic Capabilities, SSRN.

Lgagne, M., \& Discenza, R. (1993). New product costing, Japanese style. The CPA Journal Online: pp. 68-71.

Majdi, A. (2014). The Extent of Implementing Target Costing And Value Engineering Entrance To Reducing Costs Of Palestinian Shareholding Industrial Companies. Dirasat: Administrative Sciences, 41(2), 170-190.

Mansour, M. What Target Cost Is? Available: http://www.jps-dir.com/forum/uploads/13379/What_Target_Cost.pdf 


\section{Macrothink}

Asian Journal of Finance \& Accounting ISSN 1946-052X 2018, Vol. 10, No. 1

Pascoal, T., Filomena, Netob, F. J. K., \& Duffey, M. R. (2009). Target Costing Operationalization During Product Development: Model And Application. International $\begin{array}{llll}\text { Journal of Production } & \text { Economics, } & 118(2),\end{array}$ https://doi.org/10.1016/j.ijpe.2008.12.007

Talebnia, G., Baghiyan, F., Baghiyan, Z., Moussavi, F., \& Abadi, N. (2017). Target Costing, the Linkages Between Target Costing and Value Engineering and Expected Profit and Kaizen. International Journal of Engineering Management, 1(1), 11-15. 